DOI: 10.32844/2222-5374-2020-104-2.24

УДК: 342.9

Лаврентьєв $\epsilon$. O.,

здобувач Науково-дослідного інституту публічного права

\title{
РІШЕННЯ ЄВРОПЕЙСЬКОГО СУДУ З ПРАВ ЛЮДИНИ У ПРИТЯГНЕНІ ДО ВІДПОВІДАЛЬНОСТІ В УКРАЇНІ ЗА АДМІНІСТРАТИВНІ ПРАВОПОРУШЕННЯ, ПОВ'ЯЗАНІ 3 КОРУПЦІЕЮ
}

Метою статті є: охарактеризувати практику Європейського суду з прав людини у притягнені в Украӥні до відповідальності за адміністративні правопорушення, пов'язані з корупцією та назвати виявлені тенденцї. y статті охарактеризовано практику Європейського суду з прав людини у притягнені до відповідальності в Україні за адміністративні правопорушення, пов'язаніз корупцією.Автором відібрано та проаналізовано дві категорії таких судових рішень, зокрема, рішення Європейського суду з прав людини, які безпосередньо винесено у скаргах по вищезазначених видах правопорушень, а також рішення Європейського суду з прав людини, на які зроблено посилання національними судами під час розгляду справ по цих же видах правопорушень. Дослідником виокремлено спільні та специфічні тенденції у їх застосуванні. Особливу увагу приділено географії та поширенню практики. Підрахунки проведено на підставі вибірки інформації з бази даних «НUDOC» та Єдиного державного реєстру судових рішень. З'ясовано, що Європейський суд з прав людини відповідно до встановленого порядку мав перевірити три критерії прийнятності заяви. Зокрема, чи заявниця зазнала суттєвої шкоди, чи дотримання прав людини, визначених Конвенцією та доданими до неї протоколами потребує розгляду заяви по суті та чи належно розглянуто справу національним судом. 3 приводу перевірки першого параметру доводи сторін про те, що штрафє невеликим взято до уваги, а твердження заявниці щодо виникнення перешкоди на початку кар'єри державного службовця у вигляді покарання не взято до уваги. 3 даного приводу суд вважав, що не надано доказів про потенційну перспективу підвищення заявнищі по службі напередодні документування правопорушення, а також вважав, що після спливу строку стягнення вона $\epsilon$ такою, що не притягалась до відповідальності. Щодо другого критерію судової оцінки обставин справи суд не вбачав жодних вагомих підстав для того, щоб провести подальшу перевірку по суті справи.

Ключові слова: рішення, суд, правопорушення, корупція, тенденції, адміністративна відповідальність, ЄСПЛ, право на справедливий суд.

Актуальність теми. Із ратифікацією Україною Конвенції про захист прав людини і основоположних свобод від 04.11.1950 [1] (далі - Конвенція) утворено можливість звернення до Європейського суду з прав людини (далі - ЄСПЛ) та використання його практики за певних умов. 3 часом 
ухвалено Закон України «Про виконання рішень та застосування практики Європейського суду з прав людини» [2], що стало одним з найважливіших кроків у дотриманні прав людини та вдосконаленні судової практики. Відповідно до ст. 17 згаданого закону як джерело права українські суди при розгляді справ застосовують Конвенцію та практику ЄСПЛ, яку становлять його рішення. Минуло більше 14 років, тривають судові процеси у справах про адміністративні правопорушення, пов'язаних із корупцією, в рішеннях по них робились посилання на практику ЄСПЛ, рішення у справах цієї категорії оскаржувались до ЄСПЛ, але відповідну судову практику ЄСПЛ не узагальнено, за виключенням приватних досліджень та публікацій апеляційних інстанцій.

Стан дослідження. Проведено багато змістовних розвідок за різними науковими спеціальностями щодо ролі ЄСПЛ та адаптації національного законодавства, які несуть важливе теоретичне та практичне значення. До їх числа відносимо праці К.М. Рудой, О.В. Соловйова, Д.М. Супрун та інших вчених. Проте у науково-правовому плані не зроблено подібних узагальнень, дослідження в адміністративному праві є фрагментарними або загального характеру. Завдяки внеску адміністративно-правової науки існує лише декілька доробок [3-5], де вивчено практику ЄСПЛ щодо адміністративної відповідальності, яка має відношення правопорушень, пов'язаних з корупцією, в одному з них окремим питанням розглянуто практику ЄСПЛ.

Мета статті - охарактеризувати практику ЄСПЛ у притягнені в Україні до відповідальності за адміністративні правопорушення, пов'язані з корупцією та назвати виявлені тенденції.

Виклад основного матеріалу. Станом на 01.03.2020 з бази даних «HUDOC» [6] нами було відібрано 124 документи, де присутні слова «corruption» та цифри «172», які відносяться до кваліфікації досліджуваних правопорушень. Контент-аналізом 3 них виокремлено 4 рішення, що стосувались справ про адміністративні правопорушення, пов'язані 3 корупцією, суть яких можна охарактеризувати наступним чином:

Рішення від 08.01.2008 по заяві від 28.07.2001 за № 13338/02 у справі «Бойко проти України» [7]. Заявник на підставі п.п. 1 та 13 ст. 6 Конвенції скаржився, що національний суд вирішив справу про адміністративне правопорушення за його відсутності, коли він був на лікарняному. Автор скарги вважав, що суддя діяв упереджено, а докази не допустимими. Розгляд даної заяви ЄСПЛ ускладнилось тим, що необхідні заходи для розгляду справи по суті вжито, але від заявника надходжень запитуваної інформації та зауважень не було, направлені попередження про їх надання проігноровано. За таких процесуальних обставин ЄСПЛ вважав, що заявник більше не мав наміру підтримувати свою заяву, а тому її розгляд припинено у порядку п. 3 ст. 29 Конвенції, а жодна конкретна обставина, яка стосується дотримання гарантованих Конвенцією прав, не потребувала подальшого розгляду.

Рішення від 25.03.2008 по заяві № 5082/05 у справі «Судій проти України», яка подана 05.08.2004 [8]. Заявник на підставі п. 1 ст. 6 Конвенції та ст. 1 Протоколу № 1 поскаржився на невиконання судового рішення, винесеного на його користь. Вивчивши всі матеріали, ЄСПЛ вважав, що 
уряд не висунув жодного факту чи переконливого аргументу, який би переконав його дійти до іншого висновку в цій справі. ЄСПЛ встановлено, що відбулось порушення п. 1 ст. 6 Конвенції та ст. 1 Протоколу № 1, але щодо компенсації втрат від інфляції ЄСПЛ відмовлено за не підтвердженням. За цим рішенням Україна повинна виплатити заявнику протягом трьох місяців 3 дня набрання рішенням сили заборгованість, а також 2030 євро тощо.

Повідомлення від 07.12.2016 по заяві від 04.07.2013 за № 44471/13 у справі «Кондратюк проти України» [9]. Вказана заява перебуває на розгляді, рішення не прийнято. Заявник скаржився на порушення права на справедливий суд та вважав неприпустимим провадження щодо нього у справі про адміністративне правопорушення та наявним факт не проведення допиту свідка. У цій справі ЄСПЛ чекає відповідь від сторін на поставлені питання.

4) Рішення від 17.09.2019 по заяві № 35432/10 у справі «Бондаренко проти України», яка подана 05.06.2010 [10]. По суті обставин справи 29.09.2009 транспортною прокуратурою м. Кременчук складено протокол про вчинення державним службовцем корупційного адміністративного правопорушення, що виразилось у повідомленні останнім неправдивої інформації. Судом першої інстанції закрито провадження у справі на підставі відсутності події правопорушення, але за скаргою прокурора апеляційною інстанцією таке рішення суду скасовано. Подальше слухання було проведено за участі прокурора, але за відсутності заявниці та їі законного представника.

ЄСПЛ відповідно до встановленого порядку мав перевірити три критерії прийнятності заяви. Зокрема, чи заявниця зазнала суттєвої шкоди, чи дотримання прав людини, визначених Конвенцією та доданими до неї протоколами потребує розгляду заяви по суті та чи належно розглянуто справу національним судом. 3 приводу перевірки першого параметру доводи сторін про те, що штраф $\epsilon$ невеликим взято до уваги, а твердження заявниці щодо виникнення перешкоди на початку кар'єри державного службовця у вигляді покарання не взято до уваги. 3 даного приводу суд вважав, що не надано доказів про потенційну перспективу підвищення заявниці по службі напередодні документування правопорушення, а також вважав, що після спливу строку стягнення вона $є$ такою, що не притягалась до відповідальності. Щодо другого критерію судовоїоцінки обставин справи суд не вбачав жодних вагомих підстав для того, щоб провести подальшу перевірку по суті справи. Відносно останнього параметру прийнятності суд не знайшов протиріч у внутрішньому правосудді, зводячи суть даного параметру до того, що справа розглядалося національними судами на двох рівнях юрисдикції. У зв'язку з тим, що три критерії були перевірені та визнані неприйнятними, суд одноголосно вважав заяву «Бондаренко проти України» неприйнятною відповідно до пунктів 3 (b) статті 4 та пункту 4 статті 35 Конвенції.

Отже, з огляду на зміст вищерозглянутих справ стверджуємо, що практика ЄСПЛ, яка стосується притягнення до відповідальності в Україні за адміністративні правопорушення, пов'язані 3 корупцією, почала формуватись з 2001 р. та апелює з боку скаржників до порушення права на справедливий суд. Від подачі заяви до прийняття рішення пройшло від 4 до 9 років. Із цієї кількості у 3 справах рішення прийнято та по 1 - розгляд 
триває, але вони стосуються редакцій антикорупційного деліктного законодавства, що не діє або змінено чи криміналізоване.

Тепер проаналізуємо застосування посилань національними судами на практику ЄСПЛ у рішеннях, які стосуються притягнення до відповідальності за адміністративні правопорушення, пов'язані 3 корупцією. 3 ЄДРСР [11] відібрано 6 тис. рішень у справах про адміністративні правопорушення, які передбачено главою 13-А КУпАП, де у змісті рішень зустрічались словосполучення «з прав людини» та «проти». Із них виділено 2721 рішення у 405 судах по 2376 справах, де за період 3 2012 р. по 04.03.2020 року у судових рішеннях були посилання на конкретні рішення ЄСПЛ.

Аналіз засвідчив, що найбільше судових рішень 3 посиланнями припало на 2018 р., коли прийнято 1197 або 44,0 \% від усіх рішень цієї категорії, у 2019 р. - 804 (29,5\%) та 2018 - 538 (19,8\%). Судові рішення стосувались правопорушень, передбачених ст. 172-6 КУпАП у 2045 випадках (75,2\%), ст. $172-7$ - $653(24,0 \%)$, ст. $172-8$ - $14(0,5 \%)$ та $172-9$ - $9(0,3 \%)$.

$31,2 \%$ рішень припало на апеляційні інстанції. Найбільше рішень судів обох інстанцій приймалось в Одеській області, де нараховано 449 або 16,5\% від усіх рішень, Харківській - 335 (12,3\%), Дніпропетровській 179 (6,6\%), Вінницькій - 171 (6,3\%), Запорізькій - 157 (5,8\%), а найменше у Житомирській, Хмельницький, Чернівецькій, Чернігівській областях та м. Києві, де питома вага становила від 0,1 до 1,1\% рішень. При цьому, найбільше прийняли рішень апеляційні інстанції Одеської області або 214, Харківської - 94 та Вінницької областей - 54, в судах першої інстанції - Приморський районний суд м. Одеси - 67, Ленінський районний суд м. Кіровограда - 66, Жовтневий районний суд м. Дніпропетровська - 43 та Київський районний суд м. Харкова - 33.

3 огляду на можливість виділення рішень українських суддів за критерієм поширеності посилань розглянемо їх детально. Але одразу зауважимо, що жодне з нижчеперелічених рішень ЄСПЛ винесено по скаргах, які не стосувались адміністративних правопорушень, пов'язаних із корупцією.

Вище середнього використання суддями посилань було на такі рішення, як «Щокін проти України» - 46,0\%, «Білуха проти України» 7,5\%, «Коробов проти України» - 5,4\%, «Лучанінова проти України» - 4,9\%, «Волков проти України» - 4,7\%, «Веренцов проти України» - 3,8\%, «Кобець проти України» - 3,5\%, «Надточій проти України»- 2,4\%, «Карелін проти Росії» - 1,9\% та «Грабчук проти України» - 1,3\%.

Так, у рішенні «Щокін проти України» від 14.10.2010 за заявами № 23759/03 та № 37943/06 ЄСПЛ встановлено порушення процесуального аспекту ст. 2 Конвенції з огляду на те, що державними органами України не проведено жодного серйозного розслідування обставин, які призвели до смерті сина заявника під час його перебування в колонії. Розслідування обмежилося особистою відповідальністю осіб, винних у вчиненні насильницьких дій, без розгляду чи згадування питання відповідальності держави. У рішенні також вирішено питання з приводу того, що майнові права заявника були порушені в результаті незаконного накладання на нього органами державної влади додаткових зобов>язань зі сплати 
прибуткового податку. У свою чергу національні суди під час судового розгляду адміністративних правопорушень, пов'язаних із корупцією, використовували посилання на п. 56 згаданого рішення. У даному пункті ЄСПЛ виклав свою позицію, констатувавши не задоволення загальним станом національного законодавства, яке існувало на той час з питання, що розглядається у справі, відповідні правові акти явно суперечили один одному, через що національні органи на свій власний розсуд застосували протилежні підходи. Відсутність в національному законодавстві необхідної чіткості та точності, які передбачали можливість різного тлумачення такого важливого фінансового питання, порушує вимогу «якості закону», передбачену Конвенцією, та не забезпечує адекватний захист від свавільного втручання публічних органів влади [12].

Іншими словами українськими суддями робився фокус власне на концепції якості закону та захисті від свавільного втручання держави, що трактувалось, як сумнів на користь заявника. Наприклад, Апеляційним судом Кіровоградської області використано вищезазначене положення 3 рішення ЄСПЛ, після розгляду якого апеляційна інстанція зробила висновок, що право прокурора на апеляційне оскарження рішень районних суддів, у т.ч. у справах про корупційні правопорушення на законодавчому рівні не визначено та процесуально не врегульовано, що $є$ також однією 3 підстав для відмови прокурору в задоволенні даної апеляційної скарги [13]. Як наслідок, апеляція залишила у силі рішення суду першої інстанції 3 приводу закриття провадження за ч. 1 ст. 172-2 КУПАП без змін.

Менш поширеними були посилання на такі положення та такі рішення ЄСПЛ, які можемо згрупувати у такий спосіб:

1. Вимога «якості закону». Наприклад, закон має з достатньою чіткістю визначати межі правової дискреції, наданої компетентним органам, і порядок її здійснення, з урахуванням законної мети даного заходу, щоб забезпечити особі належний захист від свавільного втручання («Волох проти Польщі», «Гавенда проти Польщі», «Круслена проти Франції»); застосування принципу юридичної визначеності, чіткого врегулювання діючим законодавством («Гарькавий проти України», «Солдатенко проти України») тощо;

2. Докази та доказування - доктрина плодів отруєного дерева, відповідно до якої, якщо джерело доказів $є$ неналежним, то всі докази, отримані 3 його допомогою, будуть такими ж («Гефген проти Німеччини»); поширення стандартів, встановлених Конвенцією для кримінального провадження на провадження у справах про адміністративні правопорушення («Гурепка проти України», «Кадубець проти Словаччини») тощо;

3. Неупередженість суду - жоден із членів суду не має проявляти будьякої особистої прихильності або упередження («Бюліта проти Австрії», «Пабла Кю проти Фінляндії», «Джатрін та інші проти Франції»); презумпція неупередженості судді, за якою суддя вважається безстороннім, якщо тільки не з'являються докази протилежного («Хаушильд проти Данії») тощо;

4. Правовий статус громадянина - право на суд, одним з аспектів якого $\epsilon$ право доступу до суду, не $\epsilon$ абсолютним і може підлягати обмеженням, зокрема, щодо умов прийнятності скарг. Такі обмеження не можуть зашкоджувати самій суті права доступу до суду, мають переслідувати 
легітимну мету, а також має бути обгрунтована пропорційність між застосованими засобами та поставленою метою («Пелевін проти України», «Делкурт проти Бельгії», «Мельник проти України»); заборона переслідувати чи судити одну особу за друге правопорушення, якщо останнє походить із тих самих фактів або фактів, що по суті $є$ такими ж, як і ті, по яких мало місце перше правопорушення («Золотухін проти Росії») тощо;

5. Строки - можливість строків поновлення не буде необмеженою, оскільки сторони в розумні інтервали часу мають вживати заходів, щоб дізнатись про стан відомого їм судового провадження («Олександр Шевченко проти України»); критеріями розумних строків у судових справах $\epsilon$, в тому числі: правова та фактична складність справи, поведінка заявника, а також інших осіб, які беруть участь у справі, інших учасників процесу, поведінка органів державної влади, характер процесу та його значення для заявника («Федіна проти України») тощо;

6. Судові рішення - повноваження судів вищої інстанції переглядати справи повинні використовуватись для виправлення судових помилок та неправильності у здійсненні правосуддя; поведінка учасників судового засідання свідчить про умисний характер їх дій направлений на невиправдане затягування процесу чи зловживання своїм процесуальним правом («Юніон Аліментаріа Сандерс С.А. проти Іспанії»); при розгляді справи та призначенні стягнення потрібно досягти справедливого балансу між загальними інтересами суспільства та вимогами захисту основоположних прав особи, щоб під час відповідного втручання був дотриманий принцип законності і воно не було свавільним, тобто стягнення повинне бути пропорційним і має відповідати тяжкості та наслідкам («Ісмаїлов проти Росії», «Швидка проти України») тощо.

Крім того, звернули на себе увагу факти використання посилань на декілька положень рішень ЄСПЛ. Судді іноді звертаються до рішення, яке було винесено первісно та однакове по смислу, наприклад, у рішенні ЄСПЛ «Коробов проти України» від 21.10.2011 за заявою № 39598/03 [14] $\epsilon$ посилання на рішення від 18 січня 1978 року у справі «Ірландія проти Сполученого Королівства». На нашу думку, для зручності та недопущення маніпулювання рішеннями ЄСПЛ доцільно таку практику продовжити, але розрізняти та ввести поняття нульового рішення, під яким можемо розуміти винесене раніше, первісне чи початкове та приблизно однакове по смислу рішення.

Зафіксовано рекордне обгрунтування з 10 рішень [15], що обумовлено складністю провадження та рівнем підготовки судді.

Задля об’єктивності маємо вказати факт, коли посилання на рішення ЄСПЛ є безпідставними, як це було з рішенням «Щокін проти України», оскільки правові позиції рішення ЄСПЛ до справи не відносилися [16].

Висновки. До практики ЄСПЛ у притягнені до відповідальності в Україні за адміністративні правопорушення, пов'язані з корупцією, пропонується відносити рішення ЄСПЛ, які безпосередньо винесено у скаргах по згаданих видах правопорушень, а також рішення ЄСПЛ, на які зроблено посилання національними судами під час розгляду справ по цих же видах правопорушень. Спільним для них $є$ те, що вони стосуються права на справедливий суд, дія якого ЄСПЛ та Україною поширена 
на провадження у справах про адміністративні правопорушення за допомогою Конвенції.

У першому випадку практика $\epsilon$ незначною та почала формуватися 3 2001 р. («Бондаренко проти України», «Бойко проти України», «Судій проти України», «Кондратюк проти України») та стосується редакцій деліктного законодавства, що не діє або змінено чи криміналізовано.

У другому випадку практику вирізняють ряд тенденцій, серед яких поширене використання посилань на рішення «Щокін проти України», де суддями акцент обрано на концепції якостізаконута захисті від свавільного втручання держави, «Білуха проти України» - на упередженість або безсторонність суду, «Коробов проти України», «Волков проти України» - докази та доказування, «Лучанінова проти України» - поширення стандартів Конвенції на справи про адміністративні правопорушення. Менш поширеними $є$ посилання, але 3 більшою кількістю рішень у напрямку правового статусу громадянина, строків та судового рішення.

\section{СПИСОК ВИКОРИСТАНИХ ДЖЕРЕЛ}

1. Конвенція про захист прав і основних свобод людини від 04.11.1950. URL: https://zakon.rada.gov.ua/laws/show/995_004/ed19900101. - Назва 3 екрана.

2. Закон України від 23.02.2006 № 3477-15 «Про виконання рішень та застосування практики Європейського суду з прав людини». URL: https:// zakon.rada.gov.ua/laws/show/3477-15. - Назва з екрана.

3. Косиця 0.0. Адміністративно-правовий механізм забезпечення прав викривачів в Україні: автореф. дис. ... д-ра юрид. наук : 12.00.07; Сум. держ. ун-т. Суми, 2019. 36 с.

4. Мусієнко О.П. Адміністративно-правові заходи запобігання та протидії корупції в органах виконавчої влади і місцевого самоврядування в Україні : дис. ... канд. юрид. наук : 12.00.07; Відкр. міжнар. ун-т розвитку людини «Україна». - Київ, 2017. 242 с.

5. Іванюк В.І. Адміністративна відповідальність суддів за правопорушення, пов'язані з корупцією: дис. ... канд. юрид. наук: спец. 12.00.07. Київ, 2016. 286 с.

6. HUDOC database. URL: https://www.echr.coe.int/Pages/home. aspx?p=caselaw/HUDOC\&c=. Назва з екрана.

7. Рішення ЄСПЛ у справі «Бойко проти України» від 28.07.2001. URL: http://hudoc.echr.coe.int/eng?i=001-84619. Назва з екрана.

8. Рішення ЄСПЛ у справі «Судій проти України» від 25.03.2008. URL: http://hudoc.echr.coe.int/eng?i=001-86071. Назва з екрана.

9. Повідомлення ЄСПЛ по справі «Кондратюк проти України» від 07.12.2016. URL: http://hudoc.echr.coe.int/eng?i=001-170427. Назва з екрана.

10. Рішення ЄСПЛ у справі «Бондаренко проти України» від 17.09.2019. URL: http://hudoc.echr.coe.int/eng?i=001-196924. Назва з екрана.

11. Єдиний державний реєстр судових рішень. URL: http://reyestr. court.gov.ua/. Назва з екрана.

12. Рішення ЄСПЛ у справі «Щокін проти України» від 14.10.2010. URL: https://zakon.rada.gov.ua/laws/show/974_858. Назва з екрана. 
13. Постанова Апеляційного суду Кіровоградської області від 25.05.2016 № 58056615. URL: http://reyestr.court.gov.ua/Review/58056615. Назва з екрана.

14. Рішення ЄСПЛ у справі «Коробов проти України» від 21.07.2011. URL: https://zakon.rada.gov.ua/laws/show/974_790. Назва з екрана.

15. Постанова Вознесенського міськрайонного суду Миколаївської області від 11.05.2016. URL: http://reyestr.court.gov.ua/Review/57605646. Назва з екрана.

16. Постанова Апеляційного суду Кіровоградської області від 20.02.2014 № 37257685. URL: http://reyestr.court.gov.ua/Review/37257685. Назва з екрана.

\section{Ye. Lavrentiev}

\section{JUDGMENT OF THE EUROPEAN COURT OF HUMAN RIGHTS IN ATTORNEY TO RESPONSIBILITY IN UKRAINE FOR ADMINISTRATIVE OFFENSES RELATED TO CORRUPTION}

The purpose of the article is: to characterize the practice of the European Court of Human Rights in prosecuting administrative offenses related to corruption in Ukraine and to name the identified trends. The article describes the practice of the European Court of Human Rights in bringing to justice in Ukraine for administrative offenses related to corruption. The author selected and analyzed two categories of such court decisions, in particular, the decisions of the European Court of Human Rights, which are directly made in the complaints on the above types of offenses, as well as the decisions of the European Court of Human Rights, referred to by the national courts when considering cases on these same types of offenses. The researcher identified general and specific trends in their application. Particular attention is paid to geography and the frequency of their application. The calculations were made on the basis of a selection of information from the HUDOC database and the Unified State Register of Judicial Decisions. It was found that the European Court of Human Rights had to examine three criteria for the admissibility of the application in accordance with the established procedure. In particular, whether the applicant had suffered substantial harm, whether the observance of human rights set out in the Convention and the protocols annexed thereto required an examination of the application on the merits and whether the case had been properly examined by a national court. With regard to the verification of the first parameter, the parties' arguments that the fine was small were taken into account and the applicant's allegation of an obstacle at the beginning of the civil servant's career as a punishment was not taken into account. In this regard, the court considered that no evidence had been provided of the potential prospect of promotion of the applicant on the eve of the documentation of the offense, and also considered that after the expiry of the recovery period she had not been prosecuted. With regard to the second criterion of the court's assessment of the circumstances of the case, the court did not see any good reason to conduct a further examination of the merits of the case.

Keywords: decision, court, offenses, corruption, trends, administrative responsibility, ECHR, right to a fair trial. 